Asian J Agric \& Biol. 2021(3).

\title{
The impact of the harvesting period and drying conditions on the essential oil yield of Rosmarinus officinalis, Thymus satureioides and Origanum compactum from the Taza-Taounate region
}

\author{
Sanae Rezouki1.2*, Aimad Allali1.2, Bouchra Louasté ${ }^{3}$, Noureddine Eloutassi², Mohamed Fadli \\ ${ }^{1}$ Laboratory of Plant, Animal and Agro-industry Productions, Faculty of Sciences, University of Ibn Tofaail (ITU), Kenitra, \\ Morocco \\ ${ }^{2}$ Laboratory of Engineering, Molecular Organometallic Materials and Environment, Faculty of Sciences Dhar El Mahraz \\ (FSDM), Sidi Mohamed Ben Abdellah University (USMBA), Fez, Morocco and Regional Center for the Trades of Education \\ and Training (CRMEF), Fez, Morocco \\ ${ }^{3}$ Laboratory of Biotechnology, Environment, Agri-food and Health, Faculty of Sciences Dhar El Mahraz (FSDM), Sidi \\ Mohamed Ben Abdellah University (USMBA), Fez, Morocco
}

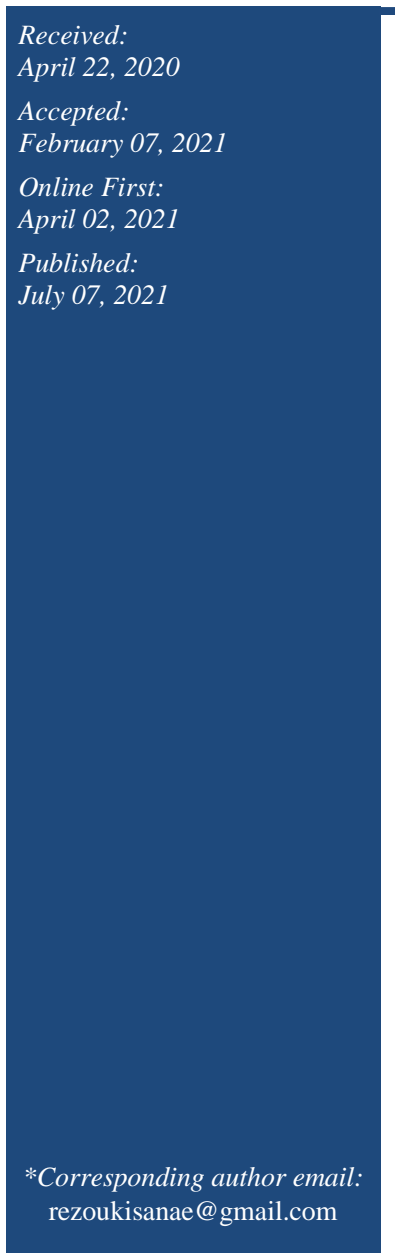

\begin{abstract}
This study focuses on the influence of the harvesting period and drying conditions on the essential oil (EO) yield of three Moroccan aromatic plants; Rosmarinus officinalis, Thymus satureioides and Origanum compactum from the Taza-Taounate region. The plants studied were harvested, determinated and dried according to a detailed protocol carried out in the laboratory. The extraction of essential oils is carried out by hydrodistillation using a Clevenger-type system in order to determine and statistically compare the yield of each sample. The results showed that drying conditions significantly affect the EO yield of the three species. For Rosmarinus officinalis, the highest yield is obtained from aerial parts dried in the shade with $1.25 \%$ for 1 to 3 days of drying and a temperature interval of 20 to $30{ }^{\circ} \mathrm{C}$. In the same conditions, an optimal yield of $1.52 \%$ is obtained for Origanum compactum. For Thymus satureioides the maximum EO content is obtained after 3 to 5 days of drying in a temperature range of 15 to $25{ }^{\circ} \mathrm{C}$. Out of these conditions, yields gradually decrease significantly to minimum yields at a 15-day drying period and a maximum temperature of $45^{\circ} \mathrm{C}$ for all plants. The harvest period is also a crucial parameter in the improvement of the EO yield, the best EO levels were recorded during the period of March-August this period corresponds to the flowering stage of the three plants, which shows that the variation of the phenological stages is a key factor in the optimization of EO yields.
\end{abstract}

Keywords: Aromatic plants, Extraction, Essential oils

\section{How to cite this:}

Rezouki S, Allali A, Louasté B, Eloutassi N and Fadli M, 2021. The impact of the harvesting period and drying conditions on the essential oil yield of Rosmarinus officinalis, Thymus satureioides and Origanum compactum from the Taza-Taounate region. Asian J. Agric. Biol. 2021(3): 202004251. DOI: https://doi.org/10.35495/ajab.2020.04.251

This is an Open Access article distributed under the terms of the Creative Commons Attribution 3.0 License. (https://creativecommons.org/licenses/by/3.0), which permits unrestricted use, distribution, and reproduction in any medium, provided the original work is properly cited. 


\section{Introduction}

Essential oils (EOs) from aromatic plants are an important source of natural medicinal and therapeutic products (Chen et al., 2020). Essential oils and their components are mainly used as food aromas; they have proven their therapeutic efficacy through their antifungal activities such as the essential oil of Melissa officinalis (El Ouadi et al., 2017), antibacterial activities such as the essential oil of Origanum compactum and Thymus satureioides ( El Bouzidi et al., 2013; Laghmouchi et al., 2018 ). Antioxidant and antiinflammatory activity, as the essential oil of Rosmarinus officinalis (Pereira et al., 2017).

The Taza-Taounate region constitutes a biogeographical unit whose characteristics model a completely original natural setting. Due to its geographical contrasts, it offers a varied range of bioclimates allowing the installation of a rich flora with marked endemism compared to the Moroccan flora (Fougrach et al., 2007 ; Khabbach et al., 2012) .Alongside this particularly promising natural context, the region has an ancestral knowledge (Mehdioui and Kahouadji, 2007), which has been preserved over the centuries: herbal medicines, their use for the flavouring and preservation of food, as well as for the extraction of aromatic principles intended for family perfumery or the market (El Rhaffari et al., 2002).

Rosemary (Rosmarinus officinalis), thyme (Thymus satureioides), oregano (Origanum compactum), are the most important medicinal species in terms of ethnobotany in Morocco (Aboukhalid et al., 2016). These are considered to be typically Moroccan products on the international market. However, yields of essential oils are subject to significant fluctuations due to climatic variations, places of origin, harvesting periods, drying conditions and extraction processes (Bakhy et al., 2014; Harsal et al., 2018; Rezouki et al., 2020; Louasté et al., 2019). The intensive and uncontrolled use of these natural resources as it is currently done in the associations and cooperatives of the MAP (Aromatic and Medicinal Plant) risks threatening the survival of several species in Morocco. Thus, sustainable development presupposes the establishment of a number of actions such as the knowledge and control of the resource's potential, the domestication of the species, the re-adaptation and the effective collaboration of all those involved in this field.

The objective of the present study is to evaluate the effects of certain valorization practices such as drying and harvesting period on the EO yield of Rosmarinus officinalis, Thymus satureioides and Origanum compactum in the Taza-Taounate region (Northern Morocco).

\section{Material and Methods}

\section{Study area and plant material}

Rosemary samples were taken from the region of Tainaste; province of Taza, for thyme from Bouaadel and oregano from Ain madouna; province of Taounte. The samples were collected periodically every month during the 2019 year.

The determination of plant species was made in the laboratory of the Botany, Biotechnology and Plant Protection Laboratory, Department of Biology, using the following flora: Practical flora of Morocco, Manual for the determination of vascular plants ( Fennane et al., 2007 ) and the verification of identifications were made with reference to the African Flowering Plant Database (APD, 2012). The geographical and climatic characteristics of each station are shown in Table 1 and Fig 1.

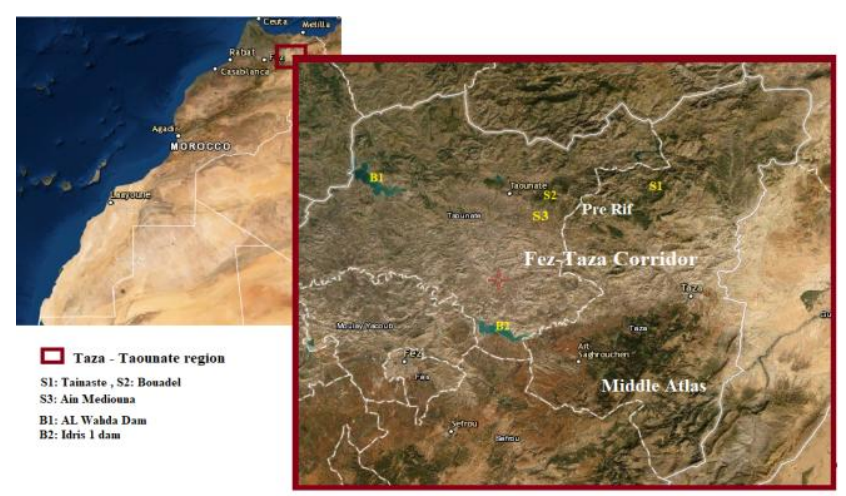

Figure-1. Geographic Distribution of the Study Area

Table -1. Geographic and climatic characteristics of the three study stations

\begin{tabular}{|c|c|c|c|c|c|}
\hline Régions & $\begin{array}{c}\text { Latitude } \\
\text { (north) }\end{array}$ & $\begin{array}{c}\text { Longitude } \\
\text { (West) }\end{array}$ & $\begin{array}{c}\text { Average } \\
\text { temperature }\left({ }^{\circ} \mathbf{C}\right)\end{array}$ & $\begin{array}{c}\text { Average precipitation } \\
(\mathbf{m m} / \mathbf{y e a r})\end{array}$ & $\begin{array}{c}\text { Climate according to } \\
\text { Köppen and Geiger }\end{array}$ \\
\hline S1: Tainaste & $34^{\circ} 55^{\prime} 2^{\prime \prime} \mathrm{N}$ & $4^{\circ} 13^{\prime} 85 \mathrm{~W}$ & 14.1 & 521 & hot and temperate \\
\hline S2: Bouadel & $34^{\circ} 33^{\prime} 0^{\prime \prime} \mathrm{N}$ & $4^{\circ} 30^{\prime} 36 \mathrm{~W}$ & 16.6 & 612 & hot and temperate \\
\hline S3: Ain Madouna & $34^{\circ} 30^{\prime} 0^{\prime \prime} \mathrm{N}$ & $4^{\circ} 33^{\prime} 0^{\prime \prime} \mathrm{W}$ & 18.0 & 601 & hot and temperate \\
\hline
\end{tabular}


For each plant, 80 samples were freshly collected and then dried in two different series. The first series was dried in shadow in a dry and airy place in the laboratory away from light at different temperatures $10,15,20,25,30,35$ and $40^{\circ} \mathrm{C}$ for $1,3,5,10,15$ days. The second series was dried under sunlight in the same conditions of temperature and drying period. The plants were harvested every month in order to deteriorate the EO content according to the monthly harvesting period; in this case the drying period was fixed at 5 days.

\section{The essential oil extraction}

The extraction of EO is carried out by hydro distillation using a Clevenger-type system, according to the guidelines of the European Directorate for the Quality of Medicines (2002).

The calculation of the essential oil content is expressed in $\mathrm{ml}$ of the distillate by $100 \mathrm{~g}$ of dry matter; it's determined by the following relation:

$$
C_{E O}=\left(\frac{V}{\mathrm{M}_{\mathrm{d}}} \times 100\right)
$$

$\mathrm{C}_{\mathrm{EO}}=$ essential oil content. $\mathrm{V}=$ volume of essential oils collected $(\mathrm{ml}) . M_{d}=$ dry plant mass $(\mathrm{g})$.

\section{Statistical analysis}

The statistical analysis of essential oil yields was carried out using IBM SPSS Statistics version 21. Statistically significant differences were determined by a two-way ANOVA followed by a Fisher's LSD test at the 5\% significance level.

\section{Results and Discussion}

\section{Effect of harvest period on essential oil yield}

The optimization of essential oil yields is one of the most important practices in the valorization of aromatic plants. It's very important to select the most productive valuation practices and determine the optimal harvest period. Table 2 showed the variations in yields of essential oils of Rosmarinus officinalis, Thymus satureioides and Origanum compactum.

The EO yield of Origanum compactum at different periods is between $0.83 \%$ and $1.52 \%$, with the lowest values during the months of November to February and the highest during the month of July. For Thymus satureioides, the highest EO yields were obtained during the period from April to September with
$0.91 \%$, the minimum yield was obtained during the month of December. For Rosmarinus officinalis, yields ranged significantly between $0.72 \%$ and $1.22 \%$, the highest values were recorded during the period from March to May (flowering period), while the lowest value was obtained during the month of August (Table 2). The yield of essential oils significantly varies from one plant to another, and for the same plant from one period to another. The results published previously also showed a large variation in EO content depending on the harvest period, Baranauskienè et al. (2013) report that the highest yield values of Origanum vulgare $L$ are obtained at the full flowering stage and slightly reduced after flowering, just before fruiting. Similar results were obtained for Salvia verbenaca L. by (Ben Farhat et al., 2019). Also, Christensen and Grevsen (2006) showed that the yield of thyme and oregano essential oils at harvest varies according to the stage of plant development. In the same direction, Dudareva and Pichersky (2000) indicated that the accumulation of essential oil during the flowering period can be the result of the compensation of the terpenes emitted by plants to attract pollinators and protect the reproductive organs against phytopathogens.

Table-2. EO content according to the monthly harvest period

\begin{tabular}{|c|c|c|c|}
\hline \multirow[b]{2}{*}{$\begin{array}{l}\text { Harvest } \\
\text { period }\end{array}$} & \multicolumn{3}{|c|}{ Average yield (\%) \pm SEM } \\
\hline & $\begin{array}{c}\text { Rosmarinus } \\
\text { officinalis }\end{array}$ & $\begin{array}{c}\text { Thymus } \\
\text { satureioides }\end{array}$ & $\begin{array}{c}\text { Origanum } \\
\text { compactum }\end{array}$ \\
\hline Mars & $1.17 \pm 0.01^{\mathrm{a}}$ & $0.81 \pm 0.05^{\mathrm{a}}$ & $1.09 \pm 0.03^{\mathrm{a}}$ \\
\hline April & $1.19 \pm 0.03^{\mathrm{a}}$ & $0.91 \pm 0.03^{b}$ & $1.22 \pm 0.09^{\mathrm{b}}$ \\
\hline May & $1.2 \pm 0.3^{\mathrm{a}}$ & $0.91 \pm 0.01^{b}$ & $1.24 \pm 0.04^{\mathrm{b}}$ \\
\hline June & $1.09 \pm 0.01^{\mathrm{a}}$ & $0.91 \pm 0.05^{\mathrm{b}}$ & $1.45 \pm 0.02^{\mathrm{c}}$ \\
\hline July & $1.09 \pm 0.02^{\mathrm{a}}$ & $0.91 \pm 0.02^{b}$ & $1.52 \pm 0.06^{\mathrm{c}}$ \\
\hline August & $0.72 \pm 0.04^{\mathrm{b}}$ & $0.90 \pm 0.015^{\mathrm{b}}$ & $1.3 \pm 0.03^{\mathrm{b}}$ \\
\hline September & $0.9 \pm 0.11^{\mathrm{b}}$ & $0.87 \pm 0.05^{\mathrm{ab}}$ & $1.19 \pm 0.1^{\mathrm{ab}}$ \\
\hline October & $0.91 \pm 0.19^{b}$ & $0.76 \pm 0.03^{\mathrm{ac}}$ & $1.01 \pm 0.04^{\mathrm{a}}$ \\
\hline November & $0.77 \pm 0.08^{b}$ & $0.51 \pm 0.09^{d}$ & $0.98 \pm 0.03^{\mathrm{d}}$ \\
\hline December & $0.72 \pm 0.11^{\mathrm{b}}$ & $0.41 \pm 0.05^{\mathrm{e}}$ & $0.86 \pm 0.02^{\mathrm{e}}$ \\
\hline January & $0.75 \pm 0.05^{\mathrm{b}}$ & $0.46 \pm 0.05^{\mathrm{de}}$ & $0.83 \pm 0.02^{\mathrm{e}}$ \\
\hline February & $0.98 \pm 0.14^{\mathrm{a}}$ & $0.51 \pm 0.04^{\mathrm{d}}$ & $0.89 \pm 0.1^{\mathrm{de}}$ \\
\hline F-value & 7.06 & 59.45 & 40.36 \\
\hline P-value & 3.41E-05 & 1.14E-14 & 9.1E-13 \\
\hline
\end{tabular}

Data are means \pm SEM of three replications.

The means in a column with different letters are significantly different $(\alpha=0.05)$. 


\section{Effect of drying time and temperature on the yield} of essential oils

The results of essential oil extraction from the aerial parts of Rosmarinus officinalis, Thymus satureioides, Origanum compactum after different drying times are shown in Table 4. And the results obtained according to the different drying temperatures are indicated in Table 3.

The results analysis showed that the drying methods used have a significant effect ( $\mathrm{p} \leq 0,05)$ on the plants' essential oil yield. The highest essential oil yield was obtained from the aerial parts of $R$. officinalis dried in the shade compared to drying under sunlight. Thus, the highest yields when drying in the sun were obtained at a temperature of $25-30^{\circ} \mathrm{C}$ and a drying time of 3 days $(1.25 \%)$ and the lowest values were obtained at a drying time of 15 days. For drying in the shade, the best yields were obtained after 3 days in a temperature range of 15 to $30^{\circ} \mathrm{C}$ with a maximum yield of $1.25 \%$ (Table3). Ahmed et al. (2018) indicated that drying methods affect EO yield and the highest yield was obtained from aerial parts of Mentha pulegium $L$. harvested in Ait ourir, Marrakech region dried in the shade.

The greatest yield of $T$. Satureioides essential oil was obtained after drying for 3 to 5 days in a temperature range of 15 to $30^{\circ} \mathrm{C}$ in the shade with a yield of about $0.91 \%$ (Table 4). This percentage is significantly higher than that obtained from the other drying periods. The low yield is obtained at 10 days drying time at a $45^{\circ} \mathrm{C}$ temperature.

The best EO yields of O. compactum were recorded after 3 days drying with a value of $1.52 \%$ at a temperature of 25 to $30{ }^{\circ} \mathrm{C}$ under sunlight. Beyond these conditions, the yields gradually decrease significantly to a minimum yield of $0.39 \%$ during 15 days of drying at a temperature of $45^{\circ} \mathrm{C}$. When drying in the shade, the highest yields were obtained in 3-day drying conditions with $1.52 \%$ at a 20 to $30{ }^{\circ} \mathrm{C}$ temperature interval. Out of these conditions, the contents decrease significantly until a minimum content of $0.42 \%$ during 15 days of drying at a temperature of $45{ }^{\circ} \mathrm{C}$.

Table-3. EO yield of Rosmarinus officinalis, Thymus satureioides, Origanum compactum according to drying temperature

\begin{tabular}{|c|c|c|c|c|c|c|}
\hline \multirow{2}{*}{$\begin{array}{c}\text { Drying } \\
\text { temperature } \\
\left({ }^{\circ} \mathrm{C}\right)\end{array}$} & \multicolumn{3}{|c|}{ In the sunshine } & \multicolumn{3}{|c|}{ in the shade } \\
\hline & $\begin{array}{l}\text { Rosmarinus } \\
\text { officinalis }\end{array}$ & $\begin{array}{c}\text { Thymus } \\
\text { satureioides }\end{array}$ & $\begin{array}{c}\text { Origanum } \\
\text { compactum }\end{array}$ & $\begin{array}{c}\text { Rosmarinus } \\
\text { officinalis }\end{array}$ & $\begin{array}{c}\text { Thymus } \\
\text { satureioides }\end{array}$ & $\begin{array}{c}\text { Origanum } \\
\text { compactum }\end{array}$ \\
\hline 10 & $0.49 \pm 0.1^{\mathrm{a}}$ & $0.81 \pm 0.01^{\mathrm{a}}$ & $1.21 \pm 0.02^{\mathrm{a}}$ & $1.01 \pm 0.15^{\mathrm{a}}$ & $0.82 \pm 0.02^{\mathrm{a}}$ & $1.21 \pm 0.02^{\mathrm{a}}$ \\
\hline 15 & $0.52 \pm 0.13^{\mathrm{a}}$ & $0.81 \pm 0.02^{\mathrm{a}}$ & $1.21 \pm 0.02^{\mathrm{a}}$ & $1.07 \pm 0.15^{\mathrm{a}}$ & $0.87 \pm 0.05^{\mathrm{ab}}$ & $1.21 \pm 0.02^{\mathrm{a}}$ \\
\hline 20 & $0.59 \pm 0.19^{\mathrm{a}}$ & $0.87 \pm 0.04^{b}$ & $1.34 \pm 0.21^{\mathrm{a}}$ & $1.14 \pm 0.16^{\mathrm{b}}$ & $0.87 \pm 0.05^{\mathrm{ab}}$ & $1.38 \pm 0.16^{b}$ \\
\hline 25 & $0.8 \pm 0.38^{\mathrm{b}}$ & $0.88 \pm 0.02^{b}$ & $1.25 \pm 0.26^{\mathrm{a}}$ & $1.12 \pm 0.18^{\mathrm{b}}$ & $0.84 \pm 0.07^{a}$ & $1.35 \pm 0.20^{\mathrm{b}}$ \\
\hline 30 & $0.65 \pm 0.34^{\mathrm{ab}}$ & $0.83 \pm 0.07^{\mathrm{a}}$ & $1.14 \pm 0.24^{\mathrm{ab}}$ & $1.03 \pm 0.17^{\mathrm{a}}$ & $0.83 \pm 0.07^{\mathrm{a}}$ & $1.32 \pm 0.23^{\mathrm{ab}}$ \\
\hline 35 & $0.58 \pm 0.32^{\mathrm{ab}}$ & $0.64 \pm 0.07^{\mathrm{c}}$ & $0.97 \pm 0.37^{\mathrm{b}}$ & $0.99 \pm 0.1^{\mathrm{a}}$ & $0.81 \pm 0.08^{\mathrm{a}}$ & $1.19 \pm 0.22^{\mathrm{ab}}$ \\
\hline 40 & $0.46 \pm 0.17^{\mathrm{ab}}$ & $0.53 \pm 0.09^{d}$ & $0.88 \pm 0.40^{\mathrm{b}}$ & $0.67 \pm 0.2^{\mathrm{c}}$ & $0.64 \pm 0.1^{\mathrm{c}}$ & $1.13 \pm 0.27^{\mathrm{a}}$ \\
\hline 45 & $0.35 \pm 0.1^{\mathrm{a}}$ & $0.47 \pm 0.05^{\mathrm{e}}$ & $0.72 \pm 0.26^{\mathrm{c}}$ & $0.57 \pm 0.1^{\mathrm{e}}$ & $0.46 \pm 0.04^{\mathrm{d}}$ & $0.84 \pm 0.36^{\mathrm{c}}$ \\
\hline LSD $_{0.05}$ & 0.194 & 0.048 & 0.16 & 0.089 & 0.054 & 0.13 \\
\hline
\end{tabular}

Means in a column followed by the same letter are not significantly different and means followed by different letters are significant at $\mathrm{P}<0.01$ in the LSD test $(\alpha=0.05)$.

Table-4. EO content of Rosmarinus officinalis, Thymus satureioides, Origanum compactum according to the drying time

\begin{tabular}{|l|c|l|c|l|l|c|}
\hline \multirow{2}{*}{ Duration } & \multicolumn{2}{|l|}{ In the sunshine } & \multicolumn{1}{l|}{ in the shade } \\
\cline { 2 - 7 } & $\begin{array}{l}\text { Rosmarinus } \\
\text { officinalis }\end{array}$ & $\begin{array}{l}\text { Thymus } \\
\text { satureioides }\end{array}$ & $\begin{array}{l}\text { Origanum } \\
\text { compactum }\end{array}$ & $\begin{array}{l}\text { Rosmarinus } \\
\text { officinalis }\end{array}$ & $\begin{array}{l}\text { Thymus } \\
\text { satureioides }\end{array}$ & $\begin{array}{l}\text { Origanum } \\
\text { compactum }\end{array}$ \\
\hline 1 day drying & $0.49 \pm 0.17^{\mathrm{a}}$ & $0.75 \pm 0.11^{\mathrm{a}}$ & $1.33 \pm 0.17^{\mathrm{a}}$ & $1.03 \pm 0.23^{\mathrm{a}}$ & $0.76 \pm 0.10^{\mathrm{a}}$ & $1.37 \pm 0.09^{\mathrm{a}}$ \\
\hline 3 day drying & $0.86 \pm 0.32^{\mathrm{b}}$ & $0.76 \pm 0.16^{\mathrm{a}}$ & $1.24 \pm 0.20^{\mathrm{ab}}$ & $1.09 \pm 0.21^{\mathrm{a}}$ & $0.82 \pm 0.16^{\mathrm{b}}$ & $1.34 \pm 0.18^{\mathrm{a}}$ \\
\hline 5 day drying & $0.62 \pm 0.23^{\mathrm{a}}$ & $0.74 \pm 0.18^{\mathrm{ab}}$ & $1.12 \pm 0.23^{\mathrm{b}}$ & $0.99 \pm 0.23^{\mathrm{a}}$ & $0.8 \pm 0.17^{\mathrm{ab}}$ & $1.28 \pm 0.21^{\mathrm{a}}$ \\
\hline 10 day drying & $0.34 \pm 0.05^{\mathrm{ac}}$ & $0.72 \pm 0.19^{\mathrm{ab}}$ & $0.94 \pm 0.28^{\mathrm{c}}$ & $0.89 \pm 0.23^{\mathrm{b}}$ & $0.74 \pm 0.18^{\mathrm{a}}$ & $1.1 \pm 0.25^{\mathrm{b}}$ \\
\hline 15 day drying & $0.34 \pm 0.05^{\mathrm{ac}}$ & $0.68 \pm 0.2^{\mathrm{b}}$ & $0.81 \pm 0.35^{\mathrm{c}}$ & $0.71 \pm 0.19^{\mathrm{c}}$ & $0.71 \pm 0.14^{\mathrm{a}}$ & $0.96 \pm 0.26^{\mathrm{c}}$ \\
\hline LSD $_{0.05}$ & 0.153 & 0.06 & 0.20 & 0.071 & 0.068 & 0.17 \\
\hline
\end{tabular}

Means in a column followed by the same letter are not significantly different and means followed by different letters are significant at $\mathrm{P}<0.01$ in the LSD test $(\alpha=0.05)$. 
Drying plants before extracting EO is an essential practice for optimizing yield; it can lead to changes in EO yield. According to Baranauskienè et al. (2013) the EO yield of fresh plants is lower than that of dried plants. After the harvest of the plants, the biosynthesis activity of terpenes and derivatives is accentuated, it's a means of defence for the plant against hydric stress that leads to an increase of essential oil yields during the first phases. After the definitive death of the plant, all the biosynthesis activity stops and the losses of essential oils by evaporation were no longer compensated, hence the drop in distillation yields as the drying days increase (Bencheikh et al., 2015).

Ghasemi et al. (2013) confirmed that drying methods for vegetable matter can affect the essential oil content negatively or positively depending on the drying time and temperature. Those results are consistent with that reported on other aromatic plants exposed to different drying methods such as Mentha pulegium $L$ harvested in Ait ourir, Marrakech region (Ahmed et al., 2018). Moreover, in this study, we have demonstrated that increasing the drying temperature reduces the yield of essential oil considerably. This observation is similar to other researchers on other aromatic plants yield such as Satureja hortensis grown in the Alborz region of Iran, (Sefidkon et al., 2006), Mentha longifolia L harvested in the Eastern Cape Province of South Africa (Asekun et al., 2007) and Laurus nobilis harvested in the El Kef region of north-western Tunisia (Sellami et al., 2011). This decrease in essential oil yield has been attributed in part to essential oil evaporation and damage to glandular trichomes in plants caused by higher drying temperatures (Argyropoulos and Müller, 2014; Ebadi et al., 2015).

\section{Conclusion}

The present study provides new information on the effect of the harvesting period and drying conditions on the EO content extracted from Rosmarinus officinalis, Thymus satureioides and Origanum compactum. The results indicate that drying time affects the EO yield of these species, the highest being observed in shade-dried samples under 3 to 5 days drying conditions at 15 to $30^{\circ} \mathrm{C}$ with respectively $1.25 \%$ for $R$. officinalis, $0.91 \%$ for $T$. satureioides and 1.52 for $O$. compactum. In addition, the harvest period has induced significant changes in EO yields, with the highest contents recorded during the spring and summer; this period corresponds to the flowering phenological stage of most aromatic and medicinal plants. The results of this study suggest that drying at a short period 3 to 5 days and 20 to $30^{\circ} \mathrm{C}$ in the shade is more appropriate to obtain a high yield of essential oil.

\section{Acknowledgement}

We would like to thank Professor Chaouch Mehdi Director of Materials and Environmental Engineering Laboratory, Faculty of Sciences Dhar El Mehraz, USMBA, Fez, Morocco.

Disclaimer: None.

Conflict of Interest: None.

Source of Funding: None.

\section{References}

Aboukhalid K, Lamiri A, Agacka- Mołdoch M, Doroszewska T, Douaik A, Bakha M, Casanova J, Tomi F, Machon N and Faiz CA, 2016.Chemical Polymorphism of Origanum compactum grown in all natural habitats in Morocco. Chem.and Biodiv. 13: 1126-1139.

Ahmed A, Ayoub K, Chaima AJ, and Abdelaziz C, 2018. Effect of drying methods on yield, chemical composition and bioactivities of essential oil obtained from Moroccan Mentha pulegium L. Biocatal. Agric. Biotechnol. 16: 638-643.

African Flowering Plant Database (APD) (version 3.1), 2012. Conservatoire et Jardin botaniques de la Ville de Genève et South African National Biodiversity Institute, Pretoria, 2012. http://www.villege.ch/musinfo/bd/cjb/africa/index.php?langue $=\mathrm{fr}$

Argyropoulos D and Müller J, 2014. Changes of essential oil content and composition during convective drying of lemon balm (Melissa officinalis L). Ind. Crops and Prod. 52: 118-124.

Asekun OT, Grierson DS and Afolayan AJ, 2007. Effects of drying methods on the quality and quantity of the essential oil of Mentha longifolia $\mathrm{L}$ subsp Capensis. Food Chem. 101: 995-998.

Bakhy K, Benlhabib O, Bighelli A, Casanova J, Tomi $\mathrm{F}$ and Faiz CA, 2014. Yield and chemical variability of the essential oil isolated from aerial parts of wild origanum compactum Benth.From 
Moroccan western rif. Am. J. E. O. Nat. Prod. 1(4): 9-17

Baranauskienė R, Venskutonis PR, Dambrauskienė E and Viškelis $\mathrm{P}, 2013$. Harvesting time influences the yield and oil composition of origanum vulgare L ssp vulgare and ssp hirtum. Ind. Crops Prod. 49:43-51.

Ben Farhat M, Sotomayor JA and Jordán MJ, 2019. Salvia verbenaca $\mathrm{L}$ essential oil: variation of yield and composition according to collection site and phenophase. Biochem. Syst. Ecol. 82: 35-43.

Bencheikh SE, Goudjil MB, Zighmi S and Ladjel S, 2015. Effet du séchage sur le rendement des huiles essentielles de la plante Teucrium polium ssp aurasianum Labiatae. AST Ann. des Sci. et Tech. 7: 1.

Chen F, Liu S, Zhao Z, Gao W, Ma Y, Wang X, Yan $S$ and Luo D, 2020. Ultrasound pre-treatment combined with microwave-assisted hydrodistillation of essential oils from Perilla frutescens (L.) Britt: leaves and its chemical composition and biological activity. Ind. Crops Prod. 143: 1-8

Christensen LP and Grevsen K, 2006. Effect of development stage at harvest on the composition and yield of essential oils from thyme and oregano, pp.261-264. In W.L.P. Bredie and M.A. Petersen (eds.), Developments in Food Science, Vol. 43. DOI: 10.1016/S0167-4501(06)80062-2

Dudareva N and Pichersky E, 2000. Biochemical and molecular genetic aspects of floral scents. Plant Physiol.122: 627-634.

Ebadi MT, Azizi M, Sefidkon F and Ahmadi N, 2015. Influence of different drying methods on drying period, essential oil content and composition of Lippia citriodora Kunth. J. App. Res. Med. Aromat. Plant. 2: 182-187.

El Bouzidi L, Jamali CA, Bekkouche K, Hassani L, Hans LD and Abbad A, 2013. Chemical composition, antioxidant and antimicrobial activities of essential oils obtained from wild and cultivated Moroccan thymus species. Ind. Crops Prod. 43: 450-456.

El Ouadi Y, Manssouri M, Bouyanzer A, Majidi L, Bendaif H, Elmsellem H, Shariati MA, Melhaoui A and Hammouti B, 2017. Essential oil composition and antifungal activity of Melissa officinalis originating from north east Morocco against postharvest phytopathogenic fungi in apples. Microb. Pathog. 107: 321-326.
El Rhaffari L, Zaid A and Lejosne JC, 2002. Pratique de la phytothérapie dans le sud-est du Maroc (Tafilalet): un savoir empirique pour une pharmacopée rénovée, pp. 293-318. In Fleurentin J. and Pelt J.M. (eds.), Des sources du savoir aux médicaments du futur : actes du $4 \mathrm{e}$ congrès européen d'ethnopharmacologie. IRD, Paris, France.

European Directorate for the Quality of Medicines, Council of Europe Editions, 2002. Determination of Essential Oils in Vegetable Drugs, fourth ed. Europea Pharmacopoea, Strasbourg, France, pp. 183-184.

Fennane M, Ibn Tattou M, Matherz J, Ouyahya A and Eloualidi J. 2007. Flore pratique du Maroc, Manuel de détermination des plantes vasculaires, Editions OKAD, Maroc 1999 \& 2007. Volume 2.

Fougrach H, Badri W and Malki M, 2007. Flore vasculaire rare et menacée du massif de tazekka : région de Taza, Maroc. Bul. de 1'Inst. Sci. Rabat. 2007(29): 1-10.

Ghasemi PA, Hashemi M and Ghahfarokhi FT, 2013. Essential oil and chemical compositions of wild and cultivated Thymus daenensis Celak and Thymus vulgaris L. Ind. Crops Prod. 48: 43-48.

Harsal AE, Mansour AI, Senhaji NS, Khay EO, Bouhdid S, Amajoud N, Farah A, Belmehdi O and Abrini J, 2018. Influence of extraction time on the yield, chemical composition, and antibacterial activity of the essential oil from Origanum elongatum harvested at northern Morocco. J. EO. Bear. Plant. 21: 1460-1474.

Khabbach A, Libiad M and Ennabili A, 2012. Production et commercialisation des ressources végétales dans la province de Taza (Nord du Maroc), Revue AFN Maroc. 2012: 6-8.

Laghmouchi Y, Belmehdi O, Senhaji NS and Abrini J, 2018. Chemical composition and antibacterial activity of origanum compactum Benth: essential oils from different areas at northern Morocco. South Afr. J. Bot.115:120-125.

Louasté B, Bouddine L and Eloutassi N, 2019. Chemical variability of rosmarinus officinalis essential oil according to the geographical origin. Der Phar. Chem.11:1.

Mehdioui R and Kahouadji A, 2007. Etude ethnobotanique auprès de la population riveraine de la forêt d'amsittène : cas de la commune d'Imi n'Tlit (province d'essaouira). Bul.de 1'Inst. Sci. Rabat. 2007(29): 11-20. 
Pereira PS, Maia AJ, Tintino SR, Oliveira-Tintino CD, Raulino IS, Vega MC, Rolón M, Coronel C, Barros LM, Duarte AE, Menezes IRA, Coutinho HDM and Silva TG, 2017. Trypanocide, antileishmania and cytotoxic activities of the essential oil from Rosmarinus officinalis $\mathrm{L}$ in vitro. Ind. Crops Prod. 109: 724-729.

Rezouki S, Allali A, Eloutassi N and Fadli M, 2020. Biotechnological valorization of aromatic plants in Morocco: impact of extraction methods on the yield and chemical composition of Origanum compactum Benth. of Taounate (Northern Morocco). P. Cell Biotech. Mol. Biol. 21:61-62

Sefidkon F, Abbasi K and Khaniki GB, 2006. Influence of drying and extraction methods on yield and chemical composition of the essential oil of Satureja hortensis. Food Chem. 99: 19-23.

Sellami IH, Wannes WA, Bettaieb I, Berrima S, Chahed T and Brahim LF, 2011. Qualitative and quantitative changes in the essential oil of Laurus nobilis L. leaves as affected by different drying methods. Food Chem.126: 691-697.

\section{Contribution of Authors}

Rezouki S: Carried out the laboratory work and wrote the article

Allali A: Performed the plant sampling in the field, collected ecological data from the study area and did the statistics and data analysis

Louasté B: Literature review, manuscript writing, manuscript final reading and approval

Eloutassi N: Designed research methodology, data collection, literature review, final reading and approval of manuscript

Fadli M: Supervised research and final approval of manuscript 